\title{
UNIVERSITYOF
}

FORWARD

THINKING

WESTMINSTER用

WestminsterResearch

http://www.westminster.ac.uk/westminsterresearch

\section{Demob Suits: One Uniform for Another? Burtons and the Leeds \\ Multiple Tailors' Production of Men's Demobilization Tailoring after the Second World War \\ Sprecher, D.}

This is a copy of the accepted author manuscript of an article published in Costume, 54

(1), pp. 108-130.

(c) Edinburgh University Press

The published version by Edinburgh University Press is available online at:

https://dx.doi.org/10.3366/cost.2020.0145

The WestminsterResearch online digital archive at the University of Westminster aims to make the research output of the University available to a wider audience. Copyright and Moral Rights remain with the authors and/or copyright owners. 


\section{Demob Suits: One Uniform for Another? Burtons and the Leeds Multiple Tailors Production of Men's Demobilisation Tailoring after the Second World War}

\section{BY DANIELLE SPRECHER}

This article focuses on the key role played by the Leeds multiple tailors in the production of tailoring for British servicemen demobilised after the Second World War. The government provided each man demobilised with a full outfit of clothing including underwear, shoes, a hat, coat and tailored wool suit - the latter commonly described as a 'demob' suit. The article explores the significance of demob suits and how they were received by the men who had to wear them, highlighting men's concern about what they wore. The public rhetoric around provision of demob suits will be considered within the context of the government restrictions on clothing of the 1940s and the way the suits were produced. The article argues that men's experience of the made-to-measure system of tailoring by the Leeds multiples influenced many servicemen's expectations about what constituted acceptable tailoring, fashion and standards of dress for their demob suits.

Keywords: Tailoring, Menswear, Demobilisation, Suits, Montague Burton Ltd, Men’s Fashion, Masculinity

\section{INTRODUCTION}

Three young men in new suits came in. The suits were blue, grey and brown; but were alike in being severely, even skimpily, cut, and in being very new. The young men who wore them - and wore them newly too were not alike, for one was tallish, fair, good-looking, and another was of similar height but dark and beaky, and the third was burly and battered. ${ }^{1}$ 
In his fictionalised account of the experiences of three men as they returned home after demobilisation from the armed services in the mid-1940s novelist J. B. Priestley (1894-1984) used the exchange of clothes from uniform to new 'demob' suit to indicate the other changes these men were soon to undergo. The demob suit was a wool tailored ready-to-wear suit the British government provided to each serviceman demobilised from 1944 to the early 1950s. The suit was part of a full outfit of clothing men received, including underwear, shoes, a hat, coat and case in which to carry them. A substantial proportion of these suits were made by a small number of Leeds-based companies who both manufactured and retailed men's made-to-measure and ready-towear tailoring. They were known as 'multiple tailors' because they distributed the clothing through branches of their own shops across the country. Historian Eric Sigsworth has estimated that a third of the total demob suits produced were made by the largest Leeds multiple tailor, Montague Burton Ltd (Burtons). ${ }^{2}$ As historian Katrina Honeyman has expertly documented, the Leeds multiples had established themselves as nationally significant producers and retailers of men's suits in the period before the Second World War and were expert in the mass production of men's tailoring. ${ }^{3}$ They had also manufactured millions of uniforms during the war, all of which made them perfectly placed to take up the challenge of manufacturing demob suits. ${ }^{4}$

This article will showcase the role of the Leeds multiple tailors in the design and production of demob suits within the context of their reception by the men who wore them and the wider public. The period of the war saw an environment created where men's clothing was up for public discussion; the usually private discourse of masculine fashion (normally characterised as being limited to that between men and their tailors) became subject to government orders, national attention and debate in parliament. Commentary and responses to the demob suit scheme, and the suits themselves, were largely framed in acceptably masculine terms with an emphasis on practicality and 
craftsmanship. Exploring both the production and the consumption of demob suits reveals the variety of men's expectations of their tailoring in the 1940s. Men wanted quality cloth and cut, garments that fitted well and were individual, they expressed frustration when the demob suits they received did not match these desires. Many of the problems stemmed from the fact that demob suits were ready-to-wear when significant numbers of men were used to having a suit made for them, largely due to the success of the Leeds multiple made-to-measure model of tailoring in the 1920s and 1930s. The public commentary and men's individual responses also highlight many men’s anxieties about having the right tailoring in order to express a correct masculine appearance in this immediate post-war period.

\section{THE LEEDS MULTIPLE TAILORS}

The model of production and retailing pioneered and refined by the Leeds multiples after the First World War through made-to-measure (sometimes called wholesale bespoke) gave men the chance to have a suit tailored to their body. Men went to a retail outlet of one of the Leeds multiple tailors such as Burtons (who in 1939 had 595 shops) or Hepworths (with 313 shops by 1945), were measured for their suit, chose the style and cloth they wanted and returned a few weeks later to collect their suit which had been cut and made up in a factory in Leeds or elsewhere in the north of England. ${ }^{5}$ The factory production and scale meant made-to-measure tailoring could be provided at a price not much more, or even equivilent to, ready-to-wear. To assist with individual cut, companies used figure charts highlighting the different types of male bodies that the cutter might have had to accommodate to make sure of a correct fit. ${ }^{6}$ There were other elements of the male body that the multiples considered important when they were attempting to manage the process of making individualised suits by mass production. Burtons included instructions on noting their customers' occupations which would have an influence on men's body types, while age was also considered significant because 
men's bodies changed as they got older. The Burtons' measuring guide noted: 'If your customer appears to be a manual labourer, this should be stated on the order form: the cutter would then use a larger sized pattern than he would for a sedentary worker. ${ }^{7}$ Burtons' largest factory, Hudson Road in Leeds, demonstrated the scale of this process - each cutter had his own table and the thousands of patterns were hung down the centre of the room - over 30,000 different patterns were available for made-to-measure tailoring (Figure 1). ${ }^{8}$

\section{AUSTERITY AND UTILITY REGULATIONS OF THE 1940S}

In order to understand the reasoning behind the provision of demob suits, and the wider clothing restrictions it is necessary to first look at the context of clothing policy during the Second World War and after. The war saw unprecedented government involvement and regulation of the entire clothing industry in Britain. ${ }^{9}$ Clothes rationing and the use of coupons was introduced in 1941, ending in 1949. Each item of clothing had a coupon value (for example a man's shirt required eight coupons) and each adult was allocated a certain number of coupons per year, but this allocation was reduced as the war progressed. By 1945, only 24 coupons for clothing were issued per person. Alongside rationing were associated 'Utility' and 'austerity' regulations and controls concerned with pricing, standards of cloth and clothing manufacture, sizing, and garment design which affected men's, women's and children's clothing. The style and design of clothing also came under scrutiny by the government with the introduction of what became known as the 'austerity' regulations. ${ }^{10}$ These consisted of controls on style by limiting the amount of material and trimmings commercial manufacturers (who made nearly all men’s outerwear including tailored suits) could use.

For men's clothing this meant, amongst other things, shortening shirt lengths, reducing the number of pockets and buttons on suits, and outlawing double-breasted suits and waistcoats, double cuffs on shirts, and turn-ups on trousers (Figure 2). ${ }^{11}$ The 
large-scale design and manufacturing processes of the Leeds multiple tailors put them at an advantage. Their form of factory mass-production was viewed as the most efficient and attractive form of clothing production by the Board of Trade - the body appointed by the wartime government to oversee these regulations - and Leeds tailoring firms such as Burtons were rewarded by being given designated status which guaranteed supplies of cloth and labour, and a market to sell to. ${ }^{12}$

It was taken for granted that women would find these style restrictions difficult to come to terms with, as Pat Kirkham has argued: "Being "fashionable” and taking a pride and interest in what you wore was an important part of “women’s culture” which did not suddenly cease because Britain was at war.' ${ }^{13}$ When introducing rationing the President of the Board of Trade, Oliver Lyttleton (1893-1972) stated: 'I know all the women will look smart but we men may look shabby. If we do, we must not be ashamed. In war the term "battle stained" is an honourable one' ${ }^{14}$ However some of the reactions belied this supposed lack of interest by men in what they wore, as the design of men's clothing became subject to the sort of scrutiny which was usually consigned to the realm of fashionable femininity. The changes in the design of men's suits under the austerity regulations were the subject of parliamentary debate. Many of the comments were negative, such as those expressed by David Robertson (1890-1970), the Conservative Member of Parliament (MP) for Streatham:

The only man who would buy one of those suits was the man who was obliged to have a suit. Anyone who was used to having four pockets in his waistcoat to hold his pen, watch-chain and diary found it very difficult to get used to two pockets, he would have to carry his fountain pen horizontally in a jacket side pocket and probably find it leaking. ${ }^{15}$

These anxieties were framed as pragmatic concerns with functionality, rather than an admittance of men's engagement with style change. This representation of masculinity 
tallied with the usual discourse around men's tailoring, that it was about craftsmanship and technical design detailing rather than fashion. In a later review of the wartime restrictions, the leading tailoring trade journal Men's Wear argued the regulations had aroused much discontent:

Austerity consisted chiefly in denying people a lot of quite small style points like pockets, ptu’s [permanent turn-ups], pleats, buttons, and so on, to which they suddenly found they had become much attached...

There arose a storm of protest from the trade and public alike which will not be forgotten by anyone who shared it and its results. ${ }^{16}$

The article went on to describe the rigours and dangers of war that both men in the armed services and male civilians had endured without protest. 'But make him wear plain bottoms on his trousers by an official Order, and he'll commit mayhem in his tailor's front shop. ${ }^{17}$ Men's Wear considered that for men being forced to forgo details such as a chain hole or to wear single breasted suits when they wanted to wear double breasted were more than enough grounds for trouble. They concluded that the reason for protest was that men did not agree with government interference in their private affairs. While the article took a semi-humorous tone, it made clear the discomfort felt when the expectations of privacy around men's clothing became public, thereby challenging the constructions of masculinity that denied men’s concern with dress. ${ }^{18}$

Significantly (and unusually in discourse relating to men's clothing), in their official history Hargreaves and Gowing also recognise the important influence of fashion in menswear with regard to the austerity regulations:

They were most valuable when they introduced minimum standards into the industry and least valuable when they tried to control fashion...In men's wear the influence of fashion meant resistance to any changes 
involving economies. Definite savings were achieved by restrictions on shirts and suits, but evasion was fairly common. ${ }^{19}$

Just as Pat Kirkham has argued in regard to women's continuing engagement with fashion during the restrictions of the war, it is clear that for men fashion still existed in the seemingly minor details of a trouser turn-up and waistcoat pocket.

In fact, the austerity regulations for men's suits only lasted two years. The Board of Trade announced in February 1944 that the design restrictions would be lifted for all men's outerwear as it was decided 'that the demobilised soldiers could not be offered civilian clothing in austerity styles. ${ }^{20}$ This had substantial implications for clothing manufacturers and retailers. The unpopularity of austerity tailoring meant that these suits would potentially be unsaleable, so the number of coupons required to purchase them was reduced from 26 to only 20 - still a significant proportion of an adult's yearly coupon allocation. Burtons also attempted to make the austerity tailoring appealing by advertising them as 'simplified' suits. ${ }^{21}$ The attitude of much of the tailoring trade to these suits could be seen in cartoons from Men's Wear in $1944 .^{22}$ One of which depicted two salesmen falling over in shock that anyone would be interested in purchasing one of these suits, even with the discounted number of coupons required. The other highlighted a particularly flashy and exaggerated style associated with the dodgy dealings of a character later defined as a 'spiv', a figure who made a living getting around the law (and rationing) and identifiable by their preferences for colour and sharp tailoring (Figure 3). ${ }^{23}$ Tellingly, all three men in the first cartoon were conspicuously wearing fashionable double breasted suits with generously cut trousers featuring wide legs and turn-ups, all design elements missing from austerity suits, and the spiv in the second flaunted an even greater excess of cloth in his suit. 
The design elements that had been excised by the austerity rules were considered to be of such importance by the government that they were not to be denied men returning from war service. Despite this acknowledgement of the significance of the style details of men's tailoring, the provision of demob suits proved to be just as controversial as the suits that conformed to the austerity regulations. The debate again thrust the design of men’s clothing into the public domain - the severe restrictions highlighted anxieties about masculinity as men underwent the visual transformation from active service into civilians through their new suit of clothes. The military uniforms worn by men during the war provided them with a defined masculine representation, visually identifying their service and sacrifice and the provision of an appropriate style and quality of menswear to those discharged was considered fundamental to the demobilisation process. A tailored suit with the correct fashionable detailing was central to the process of integrating returning servicemen back into British civilian life.

The number of demob suits required was huge: on Victory in Europe day in 1945 there were over five million Britons serving in the armed forces, and nine out of ten of these were men. ${ }^{24}$ The immense demob programme involved 'the outfitting of some five million officers and other ranks with civilian clothes of good quality’.25 However, this only applied to men, women who were demobbed from the armed services were given clothing coupons. ${ }^{26}$ In order to cope with the required numbers the vast majority of demob suits produced were ready-to-wear and were made by the wholesale men's outerwear industry that was dominated by the Leeds manufacturers. The combination of suits made by mass production and the restricted choices offered to demobilising men proved contentious particularly due to the perceptions - and reality for some men - of the inadequacies of ready-to-wear tailoring. There were also indications that men's tastes were changing, with casual styles and different cuts becoming popular. For example, a serving officer in the Royal Air Force contributed his 
conversations with fellow officers in his mess to trade journal Style for Men in 1944 where they concluded that they didn't want 'dark formal clothes' but favoured soft collars, 'two-piece tweed and flannel suits supported by a good collection of pullovers and slipovers. ${ }^{\text {, }}$ The dramatic shift from military uniform to civilian clothing by millions of men created a very public recognition of the status of men's clothed bodies and the expectations and assumptions of how they should look.

When it came to demobilisation of men from the armed forces the government was determined to improve upon the demob process of the First World War that had struggled to reintegrate men into civilian life consistently. As General Officer Commanding-in-Chief of Northern Command, Sir Philip Christison (1893-1993) commented after visiting the Burtons Hudson Road factory in 1946:

I wanted to see this for myself, after my experience at the end of the Great War of houses fit for heroes to live in, and clothes fit for heroes to wear. They were shocking things. But this time I am most impressed. The quality and workmanship amaze me. ${ }^{28}$

There was no question that the civilian clothing supplied would not consist of a tailored suit. As Mass Observation asserted in 1939, for 'all classes it is the emblem of that universal class-attribute, respectability’. ${ }^{29}$ It was agreed that the demob suit from 1944 would also improve on the austerity suits that men demobbed earlier in the war had been given. ${ }^{30}$ It was felt this would ensure that 'when the soldier steps into "civvy street” and becomes John Citizen from now on he is assured of a good suit, and he will feel a dignified citizen'. ${ }^{31}$ The idealised version of these suits was designed to conform to the expected style of 1940s tailoring: to be made of good quality wool cloth, two- or three-piece with options of single or double breasted jackets (or a more informal sports jacket and flannel trousers) and trousers with turn-ups if they were desired. 
However, the demobilisation outfit itself comprised more than just a suit, and most of the publicity and press about the scheme emphasised the variety and choice on offer to men coming out of uniform. The outfit was described as including a 'felt hat (wide choice of shape and colours), a shirt (over 100 designs) with two collars to match, tie (over 50 designs), two pairs of socks, a pair of shoes (black or brown), and a selflined raincoat. ${ }^{32}$ Significantly, the clothing provided did not require any coupons - men were given the garments separately to the rationing system, which did cause some disgruntlement from civilians, as J. B. Priestley was reported to have commented in 1945: 'the demobbed man was a prince amongst paupers - literally "a cut above the rest of us”. 33 Labour MP Evelyn Walkden (1893-1970) on being shown samples of the ensemble at a special parliamentary display thought the clothes were exceptional: 'I valued the outfit - suit, hat, shirt, shoes and underwear - shown at $£ 1717$ s. The suits were better than most MPs are wearing today'. ${ }^{34}$

Ministry of Information colour photographs of a demobilisation centre demonstrate the way the demob process was promoted, with the emphasis on individual selection and an attempt to recreate the kind of clothing consumption that men would have been familiar with (Figure 4). ${ }^{35}$ Men were sent to different demobilisation centres around the country on their return where they were processed. They were given a record and release book with tickets for each department they had to visit including a medical check, being issued with their final pay and certificate of release, and selecting their demob outfit. The demobilisation process was shown in a British Pathé newsreel film from 1945 as it followed an unnamed Royal Air Force serviceman as he demobbed through a centre in Uxbridge, West London. He admires the mocked-up tailor's window with an elegant display of the outfits on offer and feels the quality of the cloth; he peruses the style-sketches to decide what type of suit he wants; he is assisted into a ‘quieter’ patterned jacket by the civilian tailor (after rejecting the suggested 'nice, smart 
check' with the exclamation 'blimey!'); and finally admires his reflection in a fulllength mirror. ${ }^{36}$

Of course, these were idealised representations of the demob centres but Alan Allport cites positive experiences of servicemen such as one officer who described how: 'From the moment that I entered the dispersal centre until, laden with a complete civilian outfit, I emerged from the clothing store, I met nothing but quiet efficiency and outstanding courtesy. ${ }^{37}$ A pencil sketch of the process at Olympia in London’s Kensington for the Illustrated London News gives an indication of what the experience may have been like with the long Empire Hall filled with servicemen trying on suits and dealing with bundles of clothes. ${ }^{38}$ The menswear trade also appeared to be largely supportive with trade journal Style for Men approving of the way 'the submerged style interest of the new-fledged civilian was pleasantly stimulated, by allowing him a fair degree of shopping choice, and by a number of "Hints on selection", displayed on show cards. ${ }^{39}$ Ken Rawlinson who had served as a driver in the Royal Tank Regiment, remembered taking advantage of these options on his demob, choosing the more relaxed style of 'a sports coat and flannel slacks instead of the familiar "chalk stripe" demob suit'. ${ }^{40}$

The demob outfits on offer also conformed to an egalitarian ethos as both officers and privates were given the same choice of clothing. Field-Marshall Sir Bernard Montgomery (1887-1976) was reported to have chosen 'a nice dark brown herring-bone tweed suit with a thin and not too obtrusive red stripe' for his return to civvy street. ${ }^{41}$ This was quite different from the situation within the armed services where both male and female officers, who usually came from wealthier backgrounds, routinely had their uniforms individually made by bespoke and made-to-measure tailors - Burtons, for example, offered made-to-measure officers' uniforms during the war. ${ }^{42}$ As George 
Isaacs (1883-1979), the Minister of Labour, admiringly commented to Burtons workers in 1946:

In these disposal centres there is no difference in rank. There is no difference between Commissioned Officer or Non-Commissioned Officer; they all come in and take their tunic off and you don’t know whether he is a Sergeant or a Major; when he puts the suit on, it is a tribute to the garment you have supplied when you realise that it was good enough for the Colonel and the same time good enough for the Private. $^{43}$

Isaacs strongly approved of the way the demob suit had the potential to remove the class and status differentiation normally expressed by a clothed body. This chimed with much of the rhetoric of the Leeds multiple tailors throughout their history, particularly that of Burtons. ${ }^{44}$ Superficially this could be considered the case, but just as with the disparaging comments austerity suits attracted, it was in the subtle details of cut, fit and cloth that the quality and style of a man's suit was measured.

Men's awareness of these differences with demob suits was played on in cartoons advertising the Sydmor brand of Leeds tailor S. Morris \& Company in Men's Wear (Figure 5). ${ }^{45}$ One depicted a high-ranking officer flipping a coin with an ordinary serviceman for a Sydmor suit, another showed a burly naked serviceman (his modesty covered by his discarded uniform on a chair) being told that all of the Sydmor suits had gone, their superior quality giving them particular desirability. The demob garments and suits were not given makers’ or CC41 utility labels, only coded factory production labels. There were rumours that suits made by the London store Simpsons (renowned for their high quality ready-to-wear tailoring), which could be identified by their code, would be put under the counter and 'could only be obtained by asking the Quartermaster Sergeant very nicely’ while the Daily Mirror reported that civilian 
workers in some demob centres had been sacked for taking tips from servicemen for exactly that practice. ${ }^{46}$ Officers and men of the lower ranks were given the same choices of demob suits, but it is clear that there were identifiable grades of quality in demob tailoring. This was dependent on who they were made by and despite the fact that the manufacturer's name did not appear on the garments, some servicemen were aware of these quality differences and took advantage of them if they could.

The vast majority of demob tailoring production was for ready-to-wear suits (a small number of made-to-measure suits were offered to men who were considered outsize, such as Wing Commander St Loe Strachey (1901-1963) who at over six foot was given a specially made demob suit) and there were restrictions on styles and colours laid down by the Ministry of Supply. ${ }^{47}$ The options were single breasted suits with either single breasted (notched) or double breasted (pointed) lapels or double breasted suits (with pointed lapels); the suits were 'to be manufactured in various shades of Blue, Brown and Grey' ${ }^{48}$ These colours covered the most popular hues for men's suits; however, given the infinite mixtures possible in woven wools, especially tweeds, these were not as limiting as might first appear. Just as in peacetime the quality of cloth was considered one of the most important elements of a suit. The weights and types of cloth for a demob suit were also specified: 'Worsted mixture, 15 ounces; Various woollen materials from 14 to $171 / 2$ ounces; Tweeds, 16 and 17 ounces. ${ }^{49}$ Positive coverage of Burtons’ demob production at the beginning of the scheme in 1944 highlighted the diversity of cloths used and emphasised the quality and high standard of the materials available for the new civilian suits:

In this one factory's range, the 'demobbed' man will have the choice of no fewer than 47 different patterns - pin stripes, herringbone, silk stripes, twills, over-checks - the designs run the whole gamut of men's tailoring. 
Serges, worsteds, tweeds - they will all be there for the asking - each and all lined with an artificial silk twill of excellent quality. ${ }^{50}$

The publicity given to the scheme emphasised variety and aimed to conform to what had become accepted as important in men's clothing consumption. This was firmly located within the safety of men's tailoring where choice, style and quality cloth were deemed appropriately masculine.

\section{SURVIVING DEMOB SUITS}

Variety is clearly visible in a number of surviving demob suits held in museum collections. ${ }^{51}$ Leeds Museums and Galleries (LMG) have four suits, a tweed overcoat and a raincoat in their collections that have been classified as being part of the demob scheme. ${ }^{52}$ Two of the suits conform to what subsequently entered into the popular imagination as typical of a 1940s demob suit, double breasted and made of navy blue striped wool and were given to the museum by Burtons in the $1980 \mathrm{~s}^{53}$ The first belonged to a Mr F. Jordan; he was given it on demobilisation in 1946 after serving in the forces for five years. ${ }^{54}$ Made of navy worsted with a muted chalk stripe, the jacket is double breasted with a subtle curve to the collar, the two hip pockets are top jetted with flaps and it is lined in black twilled rayon. In the museum documentation it is identified as 'Style 9' - referring to a Burtons double breasted suit style, which appeared in Burtons style guides in the 1940s and earlier, though with only four buttons showing rather than the six of the demob suits (Figure 6). ${ }^{55}$ The second, which was donated by R. G. Steggles, is similarly made of navy wool, the jacket double breasted (also Style 9) with the same number of buttons and three pockets (though the hip pockets while having flaps have not been jetted). ${ }^{56}$ The suit is three-piece with a matching waistcoat and has a very different impact due to the variance in the stripes in the wool (Figure 7). Rather than one white stripe as Mr Jordan's suit has, a combination of three fine white 
stripes close together have been complimented with a fine bright blue stripe in the weave creating a bolder and brasher effect. ${ }^{57}$

As evidenced by the Burtons style guide of 1940, these suits demonstrated continuance in a silhouette from before the war with its high defined waist, square shoulders and straight trousers. Alan Allport has pointed out that the ethos of the demob suit was that it would make returning soldiers inconspicuous, which ostensibly a double breasted navy blue suit would do. ${ }^{58}$ However, Allport found many comments that clearly demonstrated the men's distaste for the uniformity and lack of fashionable styles on offer through the demobilisation centres, including this one: 'obviously a pre-war seventy-five-bob effort. Not any sort of suit I would buy...foul'. ${ }^{59}$ Some men observed the homogeneity of the suits the demobilising soldiers chose; a regularity that can be seen in the design of the navy blue stripe double breasted suits just described, despite the understated variations in the weave of the cloth: 'You looked like bookends everyone looked the same', recalled Tony Cameron , while Tom Hellawell reflected later that for the majority 'a demob suit was simply one uniform received in exchange for another. Khaki, Air Force Blue or Navy Blue, all were replaced with grey or brown chalk stripe'. ${ }^{60}$ Chalk- or pin-stripe navy blue wool became so identified with demob suits that when this style of pin-striped tailoring returned to fashion in the 1970s it was lampooned by a cartoon in the Daily Mirror ${ }^{61}$ Clearly there was no way mass production on the scale required and standardised ready-to-wear tailoring could satisfy every man’s individual tastes. But the comments also demonstrated the desire for men to differentiate themselves from each other by what they wore, even if these differences were subtle such as cloth quality or more drape in the cut of a jacket.

Other surviving demob suits show that variation in cloth could have a noticeable influence on a suit. Two of these are tweed suits, both single breasted, one held by Norfolk Museums and Archaeology Service (NMAS) made of dark grey herringbone 
tweed with a blue stripe and the other example from LMG (Figure 8). ${ }^{62}$ The NMAS suit is constructed of a very heavy-weight wool cloth, perhaps chosen for its durability, and shows little evidence of wear to the tweed. The weight of the cloth can only be ascertained through handling the garment and shows the quality of wools that were used in the making of some demob suits. The second suit, which is also in a three button single breasted style, is particularly striking because of its fawn-coloured Glen-check tweed. Suits in tweeds such as these may not have been considered suitable for all types of situations because of the historic association of tweed with the country and leisure pursuits rather than as a fabric that could be worn for office or town wear. These distinctions were recognised in the demob process as can be seen in the 1945 newsreel Demob by British Pathé where the fabric patterns on offer were divided into town wear, country wear and leisure wear. ${ }^{63}$ The combination of colour and check in the weave of the Glen-check suit make it a bold pattern to carry off, challenging any notion of being unobtrusive; it could be one of the demob suits which were described as 'gaudy' ${ }^{64}$ This danger of ridicule was frequently apparent and a way of ensuring correct expressions of masculinity. A cartoon published in Men's Wear mocked the taste of two older men dressed in garish tweeds, captioned: 'I can just imagine the ghastly suits the Government will hand out to the poor chaps after the war' ${ }^{65}$ Whether the Glen-check was deliberately chosen by a man who had the confidence to wear such a loud suit or it just happened to fit him, is impossible to know.

Fit was another aspect that was very important to men. For those used to madeto-measure suits, having to wear a suit off-the-peg was an affront to their idea of what tailoring should be, how it should look, and how it should feel to wear. Mass Observation found in 1939 that of their sample of 170 Observers 'only 14 bought readymade suits for every 86 who bought tailor-made, and in the section which paid less than $£ 4$ for its suits, the proportion was 73 tailor-made to 27 ready-made. The tailor was, in 
the majority of these cases, one of the big multiple firms, like Montagu [sic] Burton and the fifty [sic] Shilling Tailors'. ${ }^{66}$ Sir Montague Burton estimated in 1942 that 75 per cent of men's suits sold were made-to-measure. ${ }^{67}$ A tailor in Style for Men described a young Royal Air Force serviceman's demob suit brought to him in 1944, the 'quality and make was appalling, the fitting impossible; very inferior cloth, ill made, ill fitting. ${ }^{68}$ Even after extensive alteration he only considered it worthy of being worn for his work in a factory: 'If he had appeared in this suit with a red handkerchief around his neck he could have appeared as characteristic of the "underdog” of the early Victorian period. ${ }^{69}$ A Lancashire tailor reported that he had seen more than 20 ex-servicemen for alterations to their suits as they attempted to get a better fit, and when Malcolm Berwin (whose family owned Leeds tailoring company Berwin \& Berwin) came home wearing his demob suit, his father was so dismayed by it he insisted their factory make him up a new suit to be ready the next day. ${ }^{70}$ Sir Harry Secombe (1921-2001) remembered his suit ‘didn’t look too bad' after his mother and sister had helped adjust it and he was happy to wear it to meet his mates and go to a dance, and fashion designer Hardy Amies (1909-2003), who had been an intelligence officer and had his suits made by a bespoke tailor, admired the quality of the demob clothing he was given but found most of it 'rather unbecoming, except a cavalry mackintosh of excellent cut. ${ }^{, 71}$ Despite the egalitarian ethos of the demob suit, the tailoring and cut of a suit could still be a marker of status, an ill-fitting suit the cause of self-consciousness. All of these elements were crucial to the quality and design of men's tailoring with its emphasis on fit and correctness, the cloth and cut combining to create an idealised image of tailored masculinity.

While there were many complaints about demob suits, the cloths, the styles, the fit and cut, there were men who were satisfied with their new civilian tailoring. A Mass Observation file report on Clothes Buying and Wearing from 1947 noted that men's 
attitude to demob suits was mostly positive: 26 percent liked and wore their suit and only 12 percent disliked them (unfortunately there were no notes recorded about what the remaining 62 percent felt). ${ }^{72}$ A Normandy veteran, Jim, remembered his demob suit with pleasure: 'it was my first ever suit and I was very pleased with it indeed. It was a grey pinstripe suit and with it I received lovely suede shoes.' ${ }^{73}$ Soon after his demobilisation, Mr James Towns was reported by the Daily Mirror to be so proud of his demob suit that after wearing it he always put it in a press and refused to wear it in the rain. ${ }^{74}$ Contributors to the BBC's Second World War archive project Ron Goldstein and George Hedges provided photographs and descriptions of themselves wearing their demob suits after the war: Ron on his way to a wedding reception, George proudly giving his sister Winnie away at her wedding in the only suit he had ever owned. ${ }^{75}$ After serving in the Royal Fusiliers in India, North Africa and Italy, Ted Bradley wore his demob suit to his wedding to Alice Wedge in 1946 (she had to borrow her dress and veil) and while there is no record of what he thought of his suit, their wedding photograph shows him proudly standing outside the church in his three-piece single breasted (Figure 9$).^{76}$

Men also continued to wear their demob suits well after the end of the war, some because they liked them, others because they had little choice - a problem faced by Gerard Crosby - who had been amazed by the clothes on offer at the demob centre but had been forced to continue wearing his suit for several years because of the post-war difficulties in obtaining clothing. ${ }^{77}$ In 1958 the Daily Mirror featured several stories relating the durability of demob suits: Mrs R. Wood's husband had worn his for twelve years as a lounge suit and continued to wear the jacket to work, while the quality of cloth meant she had been able to cut down the now too tight trousers to make shorts for her sons. ${ }^{78}$ The diversity of opinions expressed by men about their demob suits demonstrates the difficulties in supplying ready-to-wear tailoring to male consumers 
largely used to acquiring their suits by made-to-measure and the importance men put on fit and quality for their tailoring in the 1940s.

\section{CONCLUSION}

Before the end of the Second World War discussion had begun about how men in the armed services would be reintegrated into civilian life once the conflict was over. Senior members of the government and the military were determined that men would be provided with appropriate civilian clothing - central to this was a tailored suit. The resulting demob suit conformed to contemporary public expectations of masculine attire. The significance of this was demonstrated by the decision to end the austerity regulations for men's tailoring and ensure servicemen received fashionable details of trouser turn-ups and double-breasted jackets if they wanted them. The domination of the Leeds multiples made-to-measure model prior to the war had developed to cater to individual choice giving men options in design and cloth styles, furthering established masculine tailoring consumption practices. However, the ready-to-wear tailored demob suit removed most of these choices, much to many men's frustration. The importance of men's expectations of having input into the production of their suit by choosing their cloth and tailoring details could be seen when these choices were denied them. This was a masculine form of consumption which had a strong relationship to the production and making of the garment. The demob suits given to servicemen in the 1940s made by the Leeds multiples could fall short of many men's desires because they were ready-to-wear - with perceived lack of fit and sometimes of quality.

\section{ACKNOWLEDGEMENTS}

I would like to thank members of All Saints' Church in Sedgley for putting me in touch with the family of Alice and Ted Bradley so I could get permission to publish their 
wedding photograph. I have made every effort to confirm copyright of images

reproduced from the (ceased) publication Men's Wear. Thank you to the curators who generously responded to my request to the Dress and Textiles Specialists Network about garments in their collections relating to the Leeds tailoring industry. I would also like to thank Natalie Raw and staff at Leeds Museums and Galleries for their help while I was researching my $\mathrm{PhD}$ and for permission to use images from their collections. Thank you also to Christine Stevens and Alexandra Kim for their comments and help with revisions and the anonymous peer reviewers for their constructive feedback. An AHRC Collaborative Doctoral Award in conjunction with Leeds Museums and Galleries supported the original research for this article.

\section{ORCHID}

Danielle Sprecher orcid.org/0000-0002-2570-0420

\footnotetext{
${ }^{1}$ J. B. Priestley, Three Men in New Suits (London: William Heinemann Ltd, 1945), p. 2.

${ }^{2}$ It is difficult to assess exactly how many demob suits were made by the Leeds multiple tailors in total. The figure of Burtons manufacturing a third of all demob suits was given in a 1946 report from the Manchester Daily Dispatch reprinted in the Burtons company history. The Yorkshire Evening News claimed in 1946 that clothing manufacturers in Leeds were making between a third and half of the country's weekly production of 97,000 demobilisation suits. Eric M. Sigsworth, Montague Burton: The Tailor of Taste (Manchester: Manchester University Press, 1990), p. 112; George Tansey, 'Stanley and the General', Daily Dispatch, 29 March 1946 in Ronald Redmayne, Ideals in industry: being the story of Montague Burton Ltd., 1900-1950, (Leeds: Petty \& Sons, 1951), p. 195; West Yorkshire Archive Service (hereafter WYAS), Burton Group Ltd, WYL1951/36 Private Cuttings Book No. 12, 1945-1946: 'Leeds Doing Big Demob Suits Job', Yorkshire Evening News, 2 February 1946.

${ }^{3}$ Katrina Honeyman, Well Suited: A History of the Leeds Clothing Industry 1850-1990, (Pasold Research Fund and Oxford University Press: Oxford, 2000).

${ }^{4}$ Burtons made 13,524,634 uniform garments for the British and allied army, navy and air forces - around a quarter of all uniforms produced. Redmayne, Ideals in Industry, p. 155.

${ }^{5}$ Honeyman, Well Suited, p. 60, 65.

${ }^{6}$ WYAS, Burton Group Ltd, WYL1951/136 Style books: The Trend of Fashion Exclusive Designs by Burton, 1940s, p. 60.

${ }^{7}$ WYL1951/255 Measuring Methods, by A. Designer, 1948, p. 12.

${ }^{8}$ Leeds Museums and Galleries (hereafter LMG), photograph of Hudson Road factory cutting room, LEEDM.P.2003.0001.4572; WYAS, Burton Group Ltd, WYL1951/124 P.R. Publications: Folder Photographs by Photopress (Leeds). Draft pamphlet text, 'Making of a Sports Jacket', 1952.
} 
${ }^{9}$ E.L. Hargreaves and Margaret Gowing, Civil Industry and Trade (London: HMSO, 1952), pp. 424-483; Peter McNeil, “"Put Your Best Face Forward”: The Impact of the Second World War on British Dress', Journal of Design History, 6:4 (1993), 283299; Christopher Sladen, The Conscription of Fashion: Utility Cloth, Clothing and Footwear 1941-1952 (Aldershot: Scholar Press, 1995); Helen Reynolds, 'The Utility garment: its design and effect on the mass market 1942-45', Utility Reassessed, ed. by Judy Attfield (Manchester: Manchester University Press, 1999), pp. 125-142; Geraldine Howell, Wartime Fashion: From Haute Couture to Homemade, 1939-1945 (Oxford: Berg, 2012); Julie Summers, Fashion on the Ration: Style in the Second World War (London: Profile Books, 2015).

${ }^{10}$ The Making-up of Civilian Clothing (Restrictions) Orders of 1942 and 1943.

${ }^{11}$ Hargreaves and Gowing, Civil Industry and Trade, p. 437; 'The Making of Civilian Clothing (Restrictions) Orders. 1942 No. 514', Statutory Rules and Orders: Other than those of a Local, Personal or Temporary Character for the year 1942 (London: HMSO, 1943), p. 503. The Museum of London has a suit which conforms to these regulations:

Accession Number 45.29/2a-c.

${ }^{12}$ Reynolds, 'The Utility garment', p. 130.

${ }^{13}$ Pat Kirkham, 'Fashion, femininity and "frivolous" consumption in World-War-Two Britain', Utility Reassessed, ed. by Judy Attfield (Manchester: Manchester University Press, 1999), p. 143.

${ }^{14}$ Sladen, The Conscription of Fashion, p. 20.

15 These comments were part of an extended debate by MPs about austerity suits and their sale. MP for Streatham, Mr Robertson, House of Commons Hansard. Commons Sitting of Thursday, 6th April, 1944. Austerity Suits, Fifth Series, Volume 398, Column 2212, <http://gateway.proquest.com/openurl?url_ver=Z39.88-

2004\&res_dat=xri:hcpp\&rft_dat=xri:hcpp:hansard:CDS5CV0398P0-0015> [accessed 23 August 2012].

16 'The 1914-1918 and 1939-1945 Eras', Men's Wear, 16 February 1952, p. 91.

17 'The 1914-1918 and 1939-1945 Eras', p. 91.

${ }^{18}$ See negative comments about austerity suits: Tom Hellawell, 'Yorkshire Lad: Some Folk Take Some Suiting', Open Writing

$<$ http://www.openwriting.com/archives/2004/01/some_folk_take.php> [accessed 7 September 2012]; ““Dalton’s Blunder” Say Public’, Men’s Wear, 1 February 1944, p. 17.

${ }^{19}$ For example, trouser legs could be made longer than necessary by tailors and then turned up at home. Hargreaves and Gowing, Civil Industry and Trade, p. 439.

${ }^{20}$ Hargreaves and Gowing, Civil Industry and Trade, p. 439.

${ }^{21}$ WYAS Burton Group Ltd, WYL1951/36 Newscuttings June 1944 to January 1946, The Outfitter, 8 July 1944.

${ }^{22}$ Men's Wear, 29 January 1944, p. 5; Men's Wear, 1 February 1944, p. 7.

${ }^{23}$ On the advent of the 'spiv' in the 1940s see David Hughes, 'The Spivs', The Age of Austerity, ed. by Michael Sissons and Philip French (London: Hodder and Stoughton, 1963), pp. 83-100.

${ }^{24}$ Alan Allport, Demobbed: Coming Home After the Second World War (New Haven and London: Yale University Press, 2009), p. 3.

${ }^{25}$ Board of Trade, Heavy Clothing, p. 9.

${ }^{26}$ See for example: Mary Blood, 'A WAAF Gets Demobilised', WW2 People’s War: An Archive of World War Two memories - written by the public, gathered by the BBC, <http://www.bbc.co.uk/history/ww2peopleswar/stories/38/a2754038.shtml> [accessed 25 November 2014].

${ }^{27}$ Pilot Officer, 'Here's what we think about whenever we think about “Civvies” again', Style for Men, July 1944, pp. 66-67. 
${ }^{28}$ Tansey, 'Stanley and the General', in Redmayne, Ideals in industry, p. 197.

${ }^{29}$ Mass Observation, 'Clothes', File Report A17, 1939, p. 1. Mass Observation Online, $<$ http://www.massobservation.amdigital.co.uk/Documents/Details/FileReport-A17>

[Accessed September 30, 2016].

${ }^{30}$ House of Commons Hansard. Written answers (Commons) of Wednesday, 8th

December, 1943. Demobilised Men (Austerity Suits), Fifth Series, Volume 395,

Column 980, <http://gateway.proquest.com/openurl?url_ver=Z39.88-

2004\&res_dat=xri:hcpp\&rft_dat=xri:hcpp:hansard:CAS5CV0395P0-0007> [accessed

23 August 2012]. Men who were demobbed from the navy before 1944 had been given a cash amount of $£ 2$ 19s. 4d. or a voucher for an austerity suit from Montague Burton which caused some controversy. WYAS, Burton Group Ltd, WYL1951/36

Newscuttings June 1944 to January 1946: ‘Monopoly in Sailor’s Civvy Suits Ended', Daily Mirror, 12 October 1944.

${ }^{31}$ MP for Doncaster, Evelyn Walkden, House of Commons Hansard. Commons Sitting of Thursday, 6th April, 1944. Austerity Suits, Fifth Series, Volume 398, Column 2232, $<$ http://gateway.proquest.com/openurl?url_ver=Z39.88-

2004\&res_dat=xri:hcpp\&rft_dat=xri:hcpp:hansard:CDS5CV0398P0-0015> [accessed 23 August 2012].

32 '"Civies” for the Demobilised: A Wide Choice', The Manchester Guardian, 14 March 1944, p. 5. The whole outfit was worth 56 coupons and men were also given a supplementary 90 coupons. 'Restocking the Shops', Economist, 7 July 1945, pp. 4-5.

33 J. B. Priestley, Sunday Express, 15 September 1945, p. 2 in Allport, Demobbed, p. 120.

${ }^{34}$ WYAS Burton Group Ltd, WYL1951/36 Newscuttings June 1944 to January 1946: Bill Greig, 'Navy gets a raw deal - and a shoddy suit', Daily Mirror, 13 October 1944. ${ }^{35}$ Imperial War Museum (hereafter IWM), 'Scenes at a Demobilisation Centre in Britain, 1944', TR 1583 and TR 1580, Ministry of Information Second World War Colour Transparency Collection, <http://www.iwm.org.uk/collections/item/object/205188840> and $<$ http://www.iwm.org.uk/collections/item/object/205188837> [accessed 10 September 2012].

${ }^{36}$ Demob (British Pathé, 1945), <http://www.britishpathe.com/video/demob> [accessed 18 January 2015].

${ }^{37}$ The Times, 9 July 1945, p. 5, in Allport, Demobbed, p. 121.

${ }^{38}$ Original drawing exhibited in 'Fashion on the Ration: 1940s Street Style', IWM

London, 5 March-31 August 2015. 'Clothing the Serviceman for His Return to "Civvy Street”: The Last Act in Demobilisation for All Ranks', Illustrated London News, 10 November 1945, pp. 522-523.

39 'Clothes Sense', Style for Men, April 1944, p. 247.

${ }^{40}$ Ken Rawlinson, 'A Willing Volunteer Part 3', WW2 People's War: An Archive of World War Two memories - written by the public, gathered by the BBC,

<http://www.bbc.co.uk/history/ww2peopleswar/stories/23/a7659723.shtml> [accessed 22 January 2015].

41 'Monty picks demob suit', Daily Mail, 15 November 1945, p. 3.

${ }^{42}$ Howell, Wartime Fashion, p. 56; WYAS, Burton Group Ltd, WYL1951/136 Style books: The Trend of Fashion Exclusive Designs by Burton c.1940s, naval officers' uniforms pp. 46-48, army officers pp. 54-55, RAF officers pp. 57-58.

${ }^{43}$ WYAS, Burton Group Ltd, WYL1951/36 Private Cuttings Book No 12, 1945-1946: 'Minister of Labour Visits Leeds Canteen and Thanks Workers', Leeds Guardian, 12 April 1946.

${ }^{44}$ Sigsworth, Montague Burton, p. 137.

${ }^{45}$ Men's Wear, 14 July 1945, p. 16; Men's Wear, 21 April 1945, p. 1. 
${ }^{46}$ LMG have a demob suit with Code 30, overcoat with Code 276 and raincoat with Code 65: LEEDM.S.1987.0011.21, demob suit; LEEDM.S.1987.0011.2, tweed overcoat; LEEAG.2011.0517, raincoat. The Simpsons identification was Code 11, see David Wainwright, The British Tradition: Simpson - a World of Style (London: Quiller Press, 1996), p. 56; 'Sackings for Taking Demob. Suit Tips', Daily Mirror, 7 February, 1946, p. 5.

47 'Britain's Under Secretary for Air measured up for suit - 9 October 1945', Planet News Archive, Getty Images http://www.gettyimages.co.uk/detail/news-photo/wingcommander-st-loe-strachey-member-of-parliament-for-news-photo/138582745, [accessed 3 October 2012].

${ }^{48}$ WYAS, Burton Group Ltd, WYL1951/100 - Major Milner (MP): Copy of Tender No. 819448 Supply of Civilian Suits for Demobilised Servicemen, 8 March 1947, pp. 1, 3.

${ }^{49}$ WYAS, Burton Group Ltd WYL1951/36 Newscuttings June 1944 to January 1946: 'Suits May Not Be Ready For Demobilised', Daily Telegraph, 15 September 1944.

50 'Demobilisation Suits of Pre-War Serge', The Maker-up, November 1944, in Redmayne, Ideals in industry, p. 173.

51 These are suits that have been catalogued as demob suits, usually through provenance. Some also have surviving labelling that indicate they were made as part of the demob scheme (normal manufacturers' labels were not allowed).

${ }^{52}$ LMG Burtons suits LEEDM.S.1987.0011.10; LEEDM.S.1987.0011.11;

LEEDM.S.1987.0011.14 and tweed overcoat LEEDM.S.1987.0011.2. The collection also contains demob Utility suit LEEAG.2011.0357 and demob raincoat LEEAG.2011.0517.

53 Two other similar suits are: Norwich, Norfolk Museums and Archaeology Service (hereafter NMAS), NWHCM: 1970.567; Imperial War Museum, UNI 13767-9, demob suit.

54 LMG Object File: 'Burtons Collection LEEDM.S.1987.11.1-23’, LEEDM.S.1987.0011.10.

${ }^{55}$ WYAS, Burton Group Ltd WYL1951/136 Style books: The Trend of Fashion

Exclusive Designs by Burton, Seventeenth Edition [1940], p. 9.

${ }^{56}$ LMG Object File: 'Burtons Collection LEEDM.S.1987.11.1-23',

LEEDM.S.1987.0011.11.

${ }^{57}$ LMG, LEEDM.S.1987.0011.11.

58 Allport, Demobbed, p. 119.

${ }^{59}$ Union Jack, 6 September 1945, p. 2, cited in Allport, Demobbed, p. 120.

60 Tony Cameron, Imperial War Museum: S \#12918, cited in Allport, Demobbed, p. 119; Hellawell, 'Yorkshire Lad: Some Folk Take Some Suiting'.

${ }^{61}$ 'Useless Eustace', Daily Mirror, 12 April 1975, p. 11.

62 NMAS, NWHCM: 1985.134.1-3; LMG, LEEDM.S.1987.11.14.

${ }^{63}$ Demob (British Pathé, 1945).

${ }^{64}$ Daily Express, 27 August 1945, p. 3; Soldier, 13 October 1945, p. 2 cited in Allport, Demobbed, p. 120.

${ }^{65}$ Men's Wear, 21 October 1944, p. 11.

66 The Fifty Shilling Tailors were also a Leeds Multiple. Mass Observation, 'Clothes', p. 1

${ }^{67}$ WYAS, Burton Group Ltd, WYL1951/186 Miscellaneous papers and press cuttings: Sir Montague Burton, 'Multiple tailoring in war-time’, Men’s Wear, 21 February, 1942, p. 14.

${ }^{68}$ Sam Small, 'Demob. Clothing Faults', Style for Men, August 1944, p. 116.

${ }^{69}$ Small, 'Demob. Clothing Faults', p. 116. 
70 'Sackings for Taking Demob. Suit Tips', Daily Mirror, 7 February, 1946, p. 5; LMG interview with Malcolm Berwin, 24 October 2012, LEEAG.2012.0588.

${ }^{71}$ Sir Harry Secombe, 'Me and my Demob Suit', Daily Mail, 8 May 1985, p. 20; Hardy Amies, Still Here: An Autobiography (London: Weidenfeld and Nicholson, 1984), p. 48.

${ }^{72}$ Mass Observation, 'Clothes Buying and Wearing, File Report 2502', July 1947, Mass Observation Online

$<$ http://www.massobservation.amdigital.co.uk/Contents/FileReport.aspx?documentid=2 39247\&imageid=348641\&sectionid=268873>, [accessed 4 September 2013], p. 1.

73 'My Demob Suit', WW2 People's War: An Archive of World War Two memories written by the public, gathered by the BBC, <http://www.bbc.co.uk/history/ww2peopleswar/stories/63/a3503963.shtml> [accessed 22 January 2015].

74 'Mr Towns Was So Proud of His Demob Suit', Daily Mirror, 4 February 1946, p. 4.

${ }^{75}$ Ron Goldstein, 'The Infamous Demob Suit', WW2 People's War: An Archive of World War Two memories - written by the public, gathered by the BBC

$<$ http://www.bbc.co.uk/history/ww2peopleswar/stories/95/a5875095.shtml>, [accessed 22 January 2015]; Jane Pook, 'Dad’s On About the War Again!', WW2 People’s War: An Archive of World War Two memories - written by the public, gathered by the BBC <http://www.bbc.co.uk/history/ww2peopleswar/stories/03/a2706103.shtml>, [accessed 22 January 2015].

${ }^{76}$ Alice and Ted Bradley, 1946, Gornal and Sedgley Team Ministry, <http://www.gornalandsedgley.org.uk/photos.php?pgid=19\&photoid=1301394824> [accessed 2 August 2012]; ‘Alice Bradley’s Memories of All Saints’, Gornal and Sedgley Team Ministry, http://www.gornalandsedgley.org.uk/content/pages/documents/1449938475.pdf [accessed 29 August 2019], p. 12.

${ }^{77}$ Gerard Crosby, 'Gerard Crosby - His time in the Army (Part 4)', WW2 People's War: An Archive of World War Two memories - written by the public, gathered by the BBC, <http://www.bbc.co.uk/history/ww2peopleswar/stories/14/a5921714.shtml> [accessed 22 January 2015].

78 ‘Demob Suit Records!’, Daily Mirror, 8 May 1958, p.18.

DANIELLE SPRECHER is the curator of the Westminster Menswear Archive at the University of Westminster. She was awarded her PhD in history from the University of Leeds in 2016. It investigated the design and making of British menswear by the Leeds tailoring industry and its relationship with men’s fashion between the 1940s and 1980. Her research explores everyday men's dress with a focus on object-based research. She has worked as a curator of historic dress and textile collections for a number of museums in the United Kingdom. 